\title{
Hydroxymethylated cytosine in development and disease
}

\author{
Gerd P Pfeifer \\ From Epigenetics and Chromatin: Interactions and processes \\ Boston, MA, USA. 11-13 March 2013
}

5-methylcytosine $(5 \mathrm{mC})$ is oxidized to 5-hydroxymethylcytosine $(5 \mathrm{hmC})$ by Tet proteins. The paternal $5 \mathrm{mC}$ is converted in fertilized oocytes to $5 \mathrm{hmC}$ allowing for epigenetic reprogramming of sperm DNA. Human tumors contain much lower levels of $5 \mathrm{hmC}$ compared to normal tissue. Proliferating cells in a tumor have drastically reduced levels of $5 \mathrm{hmC}$, suggesting that this stable base modification is lost during DNA replication. $5 \mathrm{hmC}$ is most abundant in cells of the nervous system. We investigated patterns of $5 \mathrm{mC}$ and $5 \mathrm{hmC}$ during neurogenesis in the embryonic mouse brain. $5 \mathrm{hmC}$ levels increase during neuronal differentiation and this modification associates preferentially with gene bodies of activated neuronal function-related genes, in which gain of $5 \mathrm{hmC}$ is often accompanied by loss of H3K27me3. Importantly, gain of $5 \mathrm{hmC}$ is rarely associated with DNA demethylation suggesting that $5 \mathrm{hmC}$ is a rather stable epigenetic mark. Functional perturbation of the H3K27 methyltransferase Ezh2 or of Tet proteins leads to defects in neuronal differentiation suggesting that formation of $5 \mathrm{hmC}$ and loss of H3K27me3 cooperate to promote brain development. We propose that the function of $5 \mathrm{hmC}$ in promoter regions is to "repair" inappropriate de novo DNA methylation but its exact mechanistic role in gene bodies is still unknown.

Submit your next manuscript to BioMed Central and take full advantage of:

- Convenient online submission

- Thorough peer review

- No space constraints or color figure charges

- Immediate publication on acceptance

- Inclusion in PubMed, CAS, Scopus and Google Scholar

- Research which is freely available for redistribution

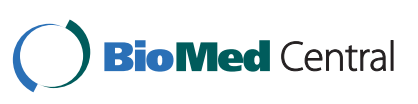

(c) 2013 Pfeifer; licensee BioMed Central Ltd. This is an Open Access article distributed under the terms of the Creative Commons Attribution License (http://creativecommons.org/licenses/by/2.0), which permits unrestricted use, distribution, and reproduction in any medium, provided the original work is properly cited. 